\title{
Role of Sulfur in Agriculture "Phosphate- Sulfur- Bentonite Mixture for Optimum Utilization of Rock Phosphate as A Fertilizer"
}

\author{
M.H. Hilal and M. M. Helal
}

Soil and Water Use Department, NRC,Giza, Egypt.

r HROUGHOUT several research and development projects, carried out by the Egypt Sulfur project at the NRC, have proved a prominent role of $\mathrm{S}$ in increasing $\mathrm{P}$ mobility to root zone; $\mathrm{P}$ uptake by plant ; crop productivity in sandy, saline calcareous and alkaline clay soils.

Semi-pilot and pilot field trials on $\mathrm{S}$ and $\mathrm{P}$ applications to soils were shown to correct several soil problems. Such applications reduce soil $\mathrm{pH}$, decrease salt accumulation, achieve ionic- balance and mobilize $\mathrm{P}, \mathrm{Fe}$ and $\mathrm{Ca}$. Such favorable effects of sulfur were promoted by mixing $\mathrm{S}$ with rock phosphate (RP) and other nutrients-carrying minerals. Results have also confirmed the effect of sulfur in promoting the efficiency of phosphate fertilizers and their uptake by plants.

A special synergetic effect between phosphates (P) and Sulfur (S) in the soil- plant system proved to increase the efficiency of each other.

Inoculation of S-P mixture with S- oxidizing bacteria enhances the oxidation of $\mathrm{S}$ and maximizes its favorable effect on soil $\mathrm{pH}$ and on $\mathrm{P}$ availability

Besides, applying bentonite clay into the mixture has increased water retention in sandy soils and increased exchangeable $\mathrm{Ca}$ on the account of free $\mathrm{Ca}$ in soil solution. Such effect on $\mathrm{Ca}$ has markedly increased phosphate availability to plants.

A special mixture of all the above-mentioned materials, RP, S, Bentonite clay and oxidizing bacteria, are now produced under the name of Agrite Phosphate.

*Agrite Phosphate is a bio-mineral sulfur-phosphate fertilizer that proved to be a superior long acting $\mathrm{P}$ fertilizer, as compared to many other phosphates.

Keywords: Agrite phosphorous, Role of S, S-P mixture, S - oxidizing bacteria, Soil pH, Exchangeable and free $\mathrm{Ca}$.

* Agrite Phosphate fertilizer is produced by Giza Fertilizers Manufacturing Co., Egypt 344 El Hegaz St, 7th Dist., 6 October City, 12451, Egypt, within a joint venture R \&DProgram, with the Egyptian Sulfur Project, National Research Centre (NRC). 
Phosphate application to soils

The quick retention of almost all the soluble phosphate fertilizer in soils is considered a worldwide agriculture problem. Only at time of application, greet differences between water soluble and none soluble sources of phosphates do appear. However, after a short time of application, most or even all forms of water soluble phosphates are retained in soils in slightly or non mobile forms. It follows that, in a short time after being added to soils, such existing differences among phosphate fertilizers count a little.

El-Neklawy (1974) added that phosphate retained in clay soils was easily released, while that retained in calcareous soils was difficult to recover. A comparative study in Holland indicated that acidified rock phosphate proved to be much more efficient than super-phosphate. Data in Table 1 show a better response of Sorghum to acidified rock phosphate than to super-phosphate.

TABLE 1. Response of sorghum to acidified-RP as compared to super phosphate.

\begin{tabular}{|c|c|c|}
\hline \multirow{2}{*}{$\begin{array}{c}\text { Soluble } \mathbf{P} \\
\text { (kg/hectare) }\end{array}$} & \multicolumn{2}{|c|}{ Yield of sorghum (kg/hectare) } \\
\cline { 2 - 3 } & Super phosphate & acidified rock-phosphates \\
\hline 0.0 & 2300 & 2300 \\
\hline 2.0 & 2400 & 2850 \\
\hline 4.0 & 2600 & 3350 \\
\hline 5.0 & 2700 & 3500 \\
\hline
\end{tabular}

Sulfur application to soil

For many years, sulfur and sulfuric acid have been used for the reclamation and improvement of alkaline soils. Elemental sulfur is transformed by soil micro-organisms to sulfuric acid, which in turn lowers soil $\mathrm{pH}$, improves soil structure, and increases the availability of certain plant nutrients, notably phosphorus

The oxidation of sulfur in soils and its consequences on other nutrients is far from being simple. Before elemental sulfur can be effective, sulfur must be oxidized in the soil to sulfuric acid. The rate of sulfur oxidation is dependent on several factors such as particle size, soil moisture content, microbial type and microbial population (Hilal, 1990).

The presence of autotrophic bacteria of the genus Thiobacillus, in soil, proved to be more than necessary.

A field experiment was conducted to study the impact of sulfur application to different soils, along with inoculation with autotrophic $S$ bacteria, on the growth and $\mathrm{P}$ uptake of wheat and corn. Treatments caused a sharp increase in corn growth and phosphate uptake in sandy and calcareous soils. 
Inoculation with S-oxidizing bacteria was several times more effective in sandy and calcareous soils as compared to its effect in clay loam soil. Besides, application rates of $\mathrm{S}$ exceeding 0.5 ton/acre were not effective.

Inoculation of Autotrophic S-oxidizing bacteria has doubled the response of corn to $\mathrm{S}$ application in sandy soil and tripled its responses in calcareous soil (Table 2).

TABLE 2. Effect of sulfur oxidizing bacteria on growth of corn plants and phosphate uptake from three different sulfur-treated soils.

\begin{tabular}{|c|c|c|c|c|c|}
\hline Soil type & Treatment & $\begin{array}{c}\text { Fresh wt. } \\
\text { g/pot. }\end{array}$ & $\begin{array}{c}\text { Dry wt. } \\
\text { g/pot. }\end{array}$ & $\begin{array}{c}\text { P concentration } \\
\text { mg/g D.W. }\end{array}$ & $\begin{array}{c}\text { P uptake } \\
\text { Mg/pot. }\end{array}$ \\
\hline \multirow{2}{*}{ Sandy } & BO & 24.6 & 4.66 & 0.70 & 3.2 \\
\cline { 2 - 6 } & BA & 57.5 & 10.85 & 0.83 & 9.0 \\
\hline \multirow{2}{*}{ Calcareous } & BO & 16.4 & 3.08 & 0.48 & 1.48 \\
\cline { 2 - 6 } & BA & 50.5 & 9.45 & 0.70 & 6.62 \\
\hline
\end{tabular}

$\mathrm{B} 0=$ no inoculation.

$\mathrm{BA}=$ Autotrophic bacteria.

Release of sulfate in S-treated soils

The oxidation of elemental $\mathrm{S}$ leads to the formation of sulfuric acid, which in turn reacts, with calcium phosphates and $\mathrm{CaCO}_{3}$ ending up with the formation of $\mathrm{CaSO}_{4}$ and the release of phosphates and other nutrients.

Data in Table 3 reveal a considerable effect of sulfur application on the formation of sulfates. The amount of $\mathrm{SO}_{4}{ }^{2-}$ increased to the double as a result of sole $\mathrm{S}$ application and to 2.5 times in case of combined application of $\mathrm{S}$ and oxidizing bacteria. Increase of sulfate formation caused a parallel increase in wheat yield, especially in salt affected soils. Sulfate formation is of great significance under conditions of saline water irrigation. Badr (1997) and Hilal et al. (1997) have shown that increasing $\mathrm{SO}_{4}{ }^{=} / \mathrm{Cl}^{-}$ratio can be an efficient corrective technique for the high salinity conditions.

TABLE 3. Sulfate release and response of wheat to applications of $S$ and $S$ oxidizing bacteria.

\begin{tabular}{|c|c|c|c|}
\hline \multicolumn{2}{|c|}{ Treatment } & \multicolumn{2}{c|}{ Wheat response at minimum soil moisture of 30\% of } \\
FC
\end{tabular}

$\mathrm{B} 0=$ no inoculation, $\quad \mathrm{BA}=$ Autotrophic bacteria. 


\section{Material and Methods}

\section{Material}

The important utilized materials in this work are the following: Phosphoric acid, Super Phosphate, Rock Phosphate, Elemental Sulfur, Bentonite and Agrite Phosphorus.

\begin{tabular}{|c|c|}
\hline \multicolumn{2}{|c|}{ Agrite Phosphorus formula } \\
\hline Oar materials & Active elements \\
\hline Rock phosphate & $\mathrm{P}_{2} \mathrm{O}_{5} \quad 22 \%$ \\
& $\mathrm{CaO} \quad 28 \%$ \\
\hline Sulfur & $\mathrm{S} \quad 15$ \\
\hline Bentonite & ------ \\
\hline Oxidation Media & ------ \\
\hline
\end{tabular}

\section{Experimental}

Successive pots and field experiments were conducted in different regions to upgrade the use of rock phosphate as an Eco-Friendly and efficient phosphate fertilizer. Different combinations' of P, S, bentonite clay and microbial culture were prepared and used for treatment of field plots or soil pots. Soil $\mathrm{pH}, \mathrm{S}$ release, mobility of $\mathrm{P}$ to rhizo-sphere, and plant response were taken as testing parameters for evaluation.

\section{Resultes and Disscusion}

Effect of $S$ on soil $p H$ and available $P$

Sulfur application to soils caused marked decrease in the $\mathrm{pH}$ of all Soils. Drop in soil $\mathrm{pH}$ indicates the occurrence of $\mathrm{S}$ oxidation to sulfuric acid, in all tested soils.

However, the effect of sulfur on soil $\mathrm{pH}$ was not similar to its effect on phosphorus availability or on yield (Fig.1).

When the soil was enriched with phosphate fertilizer at the time of sulfur incubation, a great difference was noticed in the effect of sulfur on the availability of phosphorus in soils. Available phosphate was almost doubled in Radwania soil due to sulfur application while a negative or no response to sulfur application appeared in both Ishaki and Diala soils when enriched with phosphates.

The behavior of the soils with respect to phosphate solubility and extraction is thought to be primarily related to the ratio of clay to $\mathrm{CaCO}_{3}$ content in the soil, rather than to either of these factors separately.

Egypt. J. Soil Sci. 53, No. 3 (2013) 


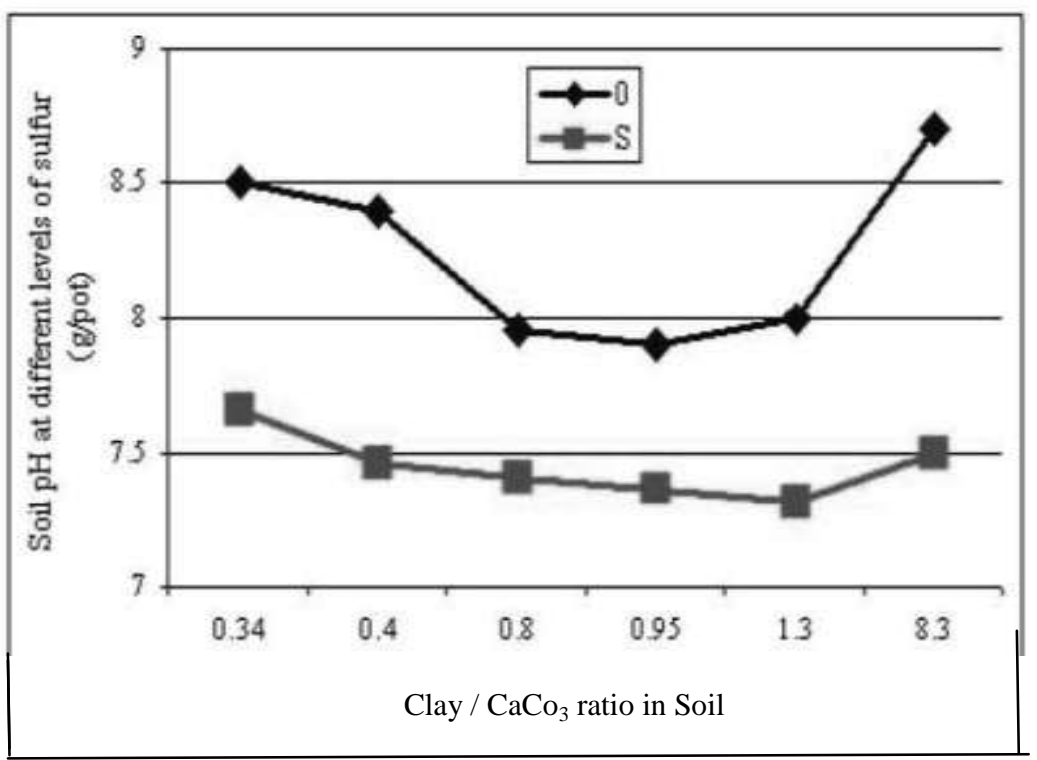

Fig. 1. Changes in Soil pH two months after sulfur application to six different (Clay / $\mathrm{CaCo}_{3}$ ratio in Soil).

The effect of $\mathrm{CaCO}_{3}$ to clay ratio on the response of native and added phosphorus to different levels of sulfur application to soils is also shown in Fig.2 Levels of added $\mathrm{S}$ were 0,20 and $40 \mathrm{~g} /$ pot. The increase in this ratio was parallel to $\mathrm{P}$ fixation. The effect of $\mathrm{CaCO}_{3}$ on phosphate fixation is well known especially when calcium solubility is increased due to sulfur application, the subsequent drop in soil $\mathrm{pH}$ may result in a precipitation of calcium phosphate in a separate phase, which is converted over time to insoluble phosphate granules.

On the other hand, the increase in clay content tends to increase the reactive surface and consequently increase calcium retention in an exchangeable form which attracts phosphate to the clay surface, where it is held in an easily extractable form.

Calcium in this case may work as a linkage between the clay surface and phosphate ions. Thus, it can be postulated that the increase in exchangeable calcium increased extractable phosphates, while soluble calcium present in soil solution resulted in precipitation of calcium phosphates away from clay, thereby decreasing phosphate solubility. 


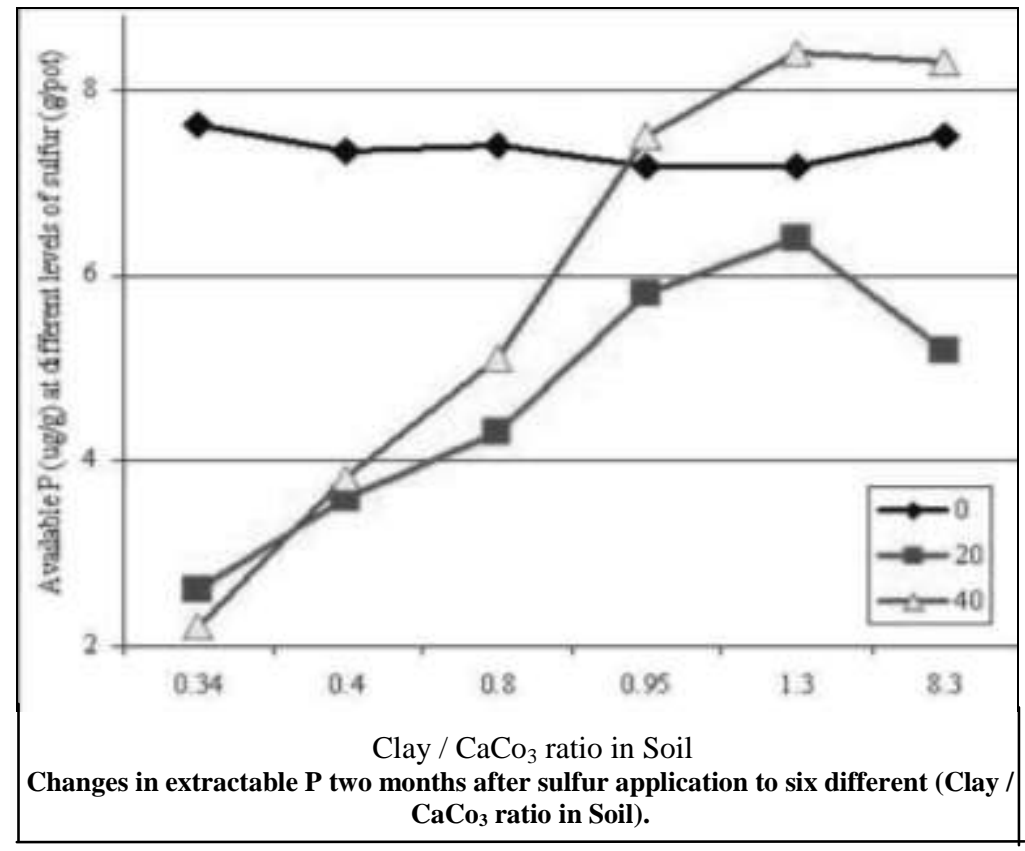

Fig. 2. Effect of $\mathrm{CaCO}_{3}$ to clay ratio on soil available $\mathrm{P}$.

Yield response of barley to added sulfur and phosphorus in different soils

In another study, six soils from Egypt and Iraq representing a wide range of $\mathrm{CaCO}_{3}$-to-clay ratios were selected for use in pot and laboratory studies. The effect of sulfur and phosphate application, on soil $\mathrm{pH}$, available phosphate, $\mathrm{P}$ uptake and yield of barley were evaluated.

The yield of barely dry matter per pot was shown to respond greatly to sulfur application in clay loam soils. This is in contrast to a slight or no response in loam and sandy soils that contain a high percentage of $\mathrm{CaCO}_{3}$. However, the application of a high rate of sulfur (40 g/pot) resulted in lower yields in all soils, as compared to the other two levels of application. Furthermore, the level of sulfur at which the optimum yield was obtained changed from soil to soil.

The application of sulfur to a highly calcareous soil, of very low clay content, decreased sharply the soil available phosphorus to almost $30 \%$ of that of sulfur nontreated soil (Fig. 2). The oxidation of added $\mathrm{S}$ to $\mathrm{H}_{2} \mathrm{SO}_{4}$ dissolved $\mathrm{CaCO}_{3}$ increased $\mathrm{Ca}^{++}$ions in soil solution ; consequently precipitated $\mathrm{P}$ in a tri-calcium phosphate form. It thus decreased available P. 
Effect of clay level on promoting the effect of sulfur and phosphorus in soils

The yield response to sulfur seems also to be a function of the ratio of $\mathrm{CaCO}_{3}$ to clay in the soil. Soils with $\mathrm{CaCO}_{3}$-to-clay ratios equal to or larger than 1.25 as shown in Fig. 3 caused little or no effect on yield. However, the response to sulfur in soils with a high $\mathrm{CaCO}_{3}$ /clay ratio was considerably increased by adding phosphate fertilizers.

This effect of phosphates on yield responses in soils of low $\mathrm{CaCO}_{3}$-to-clay ratios was not clear except at the highest level of sulfur application. Thus the application of clays to soils of $\mathrm{CaCO}_{3}$ /clay ratio $\geq 1.25$ is expected to cause a great increase in crop yield and nutrients uptake upon sulfur application.

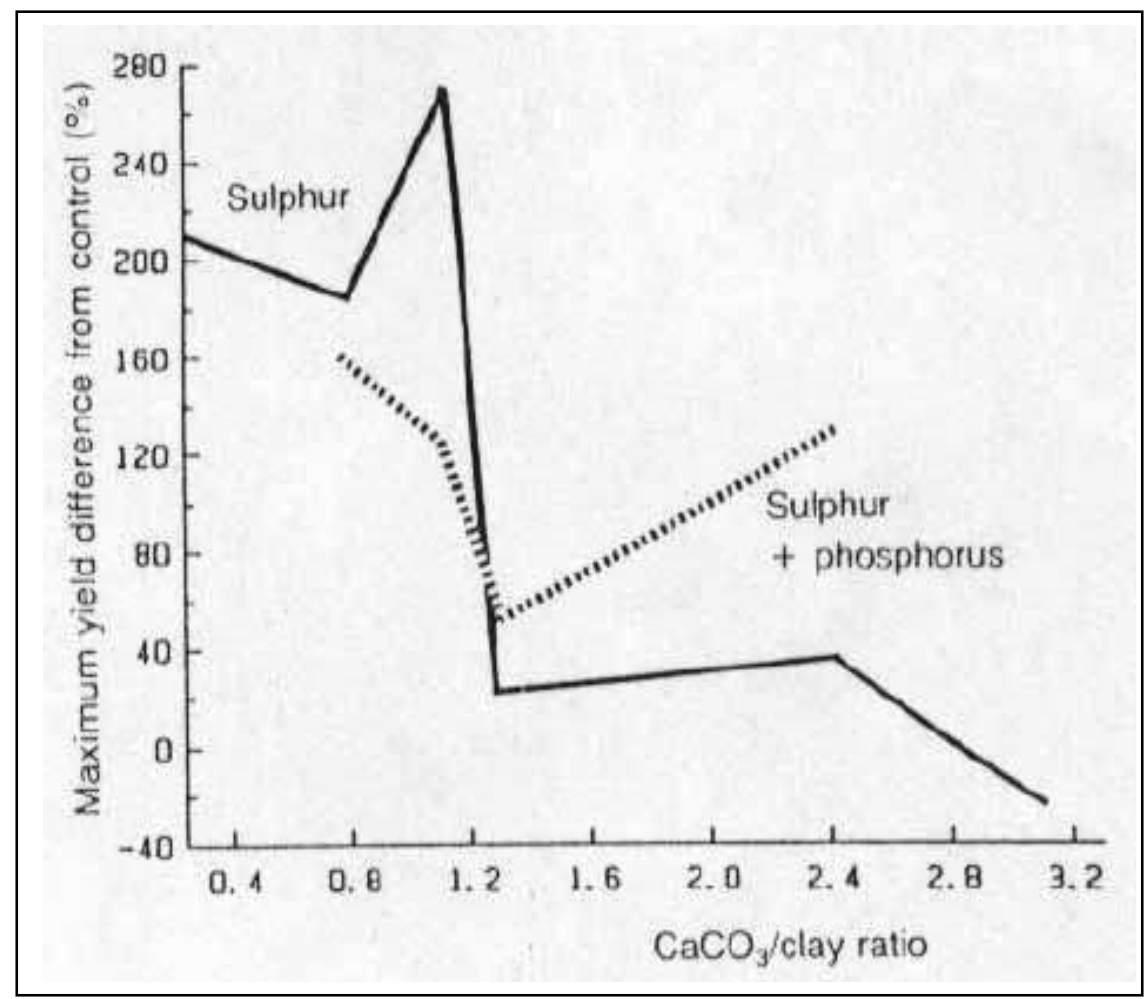

Fig. 3. Effect of $\mathrm{CaCO}_{3} /$ clay ratio on the yield response of barley to $\mathrm{S}$ application.

Effect of $S$ and $P$ on properties of root zone

A field experiment was conducted in a virgin sandy soil, cultivated for the first time with lupine. Normal practices were applied to all field plots. Sulfur (at a rate of $200 \mathrm{~kg} / \mathrm{acre}$ ), super-phosphate (at a rate of $100 \mathrm{~kg} / \mathrm{acre}$ ) and combined 
S \& P (PS) were applied at random to certain plots. Effects of treatments on nutrient movement to root zone and on depth of root penetration were evaluated.

Even though sulfur was mixed with the topsoil, considerable effect on the $\mathrm{pH}$ and phosphate content of subsurface soil was obtained. Only 4 weeks after sulfur application, $\mathrm{pH}$ of the root zone dropped from 8.0 in control plots to 7.7 in $\mathrm{S}$ treated plots. Phosphate availability in the same zone increased from few ppm in control plots to $35 \mathrm{ppm}$ in phosphate treated plots to more than $85 \mathrm{ppm}$ in $\mathrm{S}+\mathrm{P}$ treated plots (Fig. 4). Movement of sulfate from topsoil was also increased several folds.

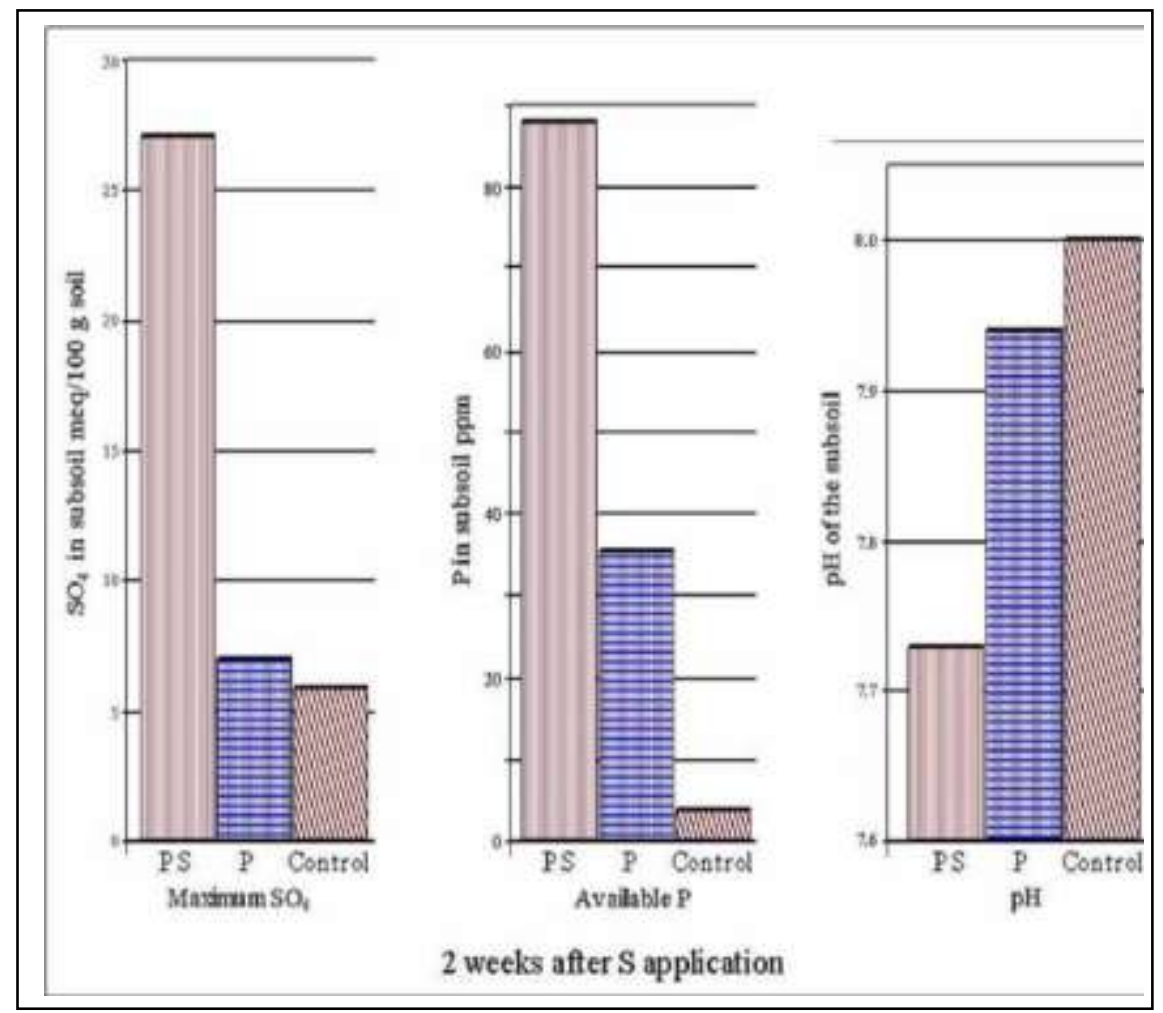

Fig. 4. Effect of phosphorus and sulfur applications on certain properties of root zone, 2 weeks after application.

Movement of nutrients to subsurface and drop of $\mathrm{pH}$ seemed to maintain better growth conditions for root growth, it was shown that active root zone did not exceed $6 \mathrm{~cm}$ depth in $\mathrm{S}$ non treated plots compared to a zone of 25 to $35 \mathrm{~cm}$ in sulfur treated plots. Maximum root penetration depth increased from $25 \mathrm{~cm}$ to $65 \mathrm{~cm}$ due to application of $200 \mathrm{~kg} \mathrm{~S} /$ acre. 


\section{Interaction effects of $S$ and $P$}

Due to discrepancies in results concerning the effect of $S$ application on plant growth, in contrary to its emphasized effect on soil properties, it was thought important to investigate further the enhancing and retarding effects of different sulfur applications on plant production under different soil types. Therefore, field trials were conducted in sandy, calcareous and clay loam soils. The impact of different rates of $\mathrm{S}$ and $\mathrm{P}$ applications on some crops were evaluated.

A field study was conducted to evaluate the interaction effect of $\mathrm{P}$ and $\mathrm{S}$ on the yield of garlic at the National Res. Center experimental farm in South Delta, Egypt. Results indicated a positive combined effect of sulfur and $\mathrm{P}$ on the yield of garlic.

Combined application of $\mathrm{S}$ and $\mathrm{P}$ was shown to increase the yield of garlic by $21 \%$. The positive effect of $\mathrm{S}$ on bulb weight exceeded its effect on total garlic yield (Table 4). S seems to contribute mostly to the eatable part while $\mathrm{P}$ and $\mathrm{N}$ contribute to total yield with straw included.

TABLE 4. Effect of different $S$ and $P$ applications on the yield of garlic in a clay loam soil.

\begin{tabular}{|c|c|c|c|c|c|c|}
\hline \multirow{3}{*}{ S (ton/fed) } & \multicolumn{5}{|c|}{ Yield ton/fed } & \multicolumn{3}{c|}{ Average weight of bulb g } \\
\cline { 2 - 7 } & \multicolumn{5}{|c|}{ P-levels (kg/acre) } \\
\cline { 2 - 7 } & $\mathbf{1 0 0}$ & $\mathbf{2 0 0}$ & $\mathbf{3 0 0}$ & $\mathbf{1 0 0}$ & $\mathbf{2 0 0}$ & $\mathbf{3 0 0}$ \\
\hline 0.0 & 4.10 & 4.90 & 5.20 & 26.5 & 27.8 & 28.3 \\
\hline 0.5 & 5.10 & 5.90 & 6.30 & 38.5 & 43.7 & 44.5 \\
\hline 1.0 & 5.80 & 6.20 & 6.60 & 43.0 & 48.2 & 50.7 \\
\hline 2.0 & 6.00 & 6.90 & 7.10 & 49.4 & 53.9 & 55.2 \\
\hline
\end{tabular}

As shown in Fig. 4 the application of super phosphate alone to a loamy soil caused a little effect on soil $\mathrm{pH}$ and on sulfate release but caused a moderate increase on available $\mathrm{P}$. Combined $\mathrm{S}+\mathrm{P}$ application, on the other hand, has greatly increased the available soil $\mathrm{P}$ and the formation of sulfate. Besides, a noticeable reduction in soil $\mathrm{pH}$ did occur.

\section{Agrite phosphate}

Soluble phosphate compounds that are available in markets are commonly used as fertilizers are: phosphoric acid; super- phosphate; triple- phosphate; diammonium phosphate and potassium phosphate. Phosphates of these compounds are precipitated or fixed quickly in the soil, in forms that are not available to plant roots.

With that respect Jones and Field (1978) introduced a biological phosphate fertilizer, under the name of Biosuper, consisting of rock phosphate, elemental S and an inoculums of thiobacilli. They stated that Biosuper compared quite 
favorably with superphosphate. Moreover, Basharati et al. (2007) indicated that Biosuper, which is a rock phosphate- bio-fertilizer, increased plant parameters significantly compared with control or rock phosphate treatment.

Khasawneh and Doll (1978) stated that the relative agronomic effectiveness of different sources of rock phosphates were different, certain sources can be used for direct application to soils as phosphate fertilizer. Data presented in Fig.5 show that the response of maize to different American sources of rock phosphate were greatly different.

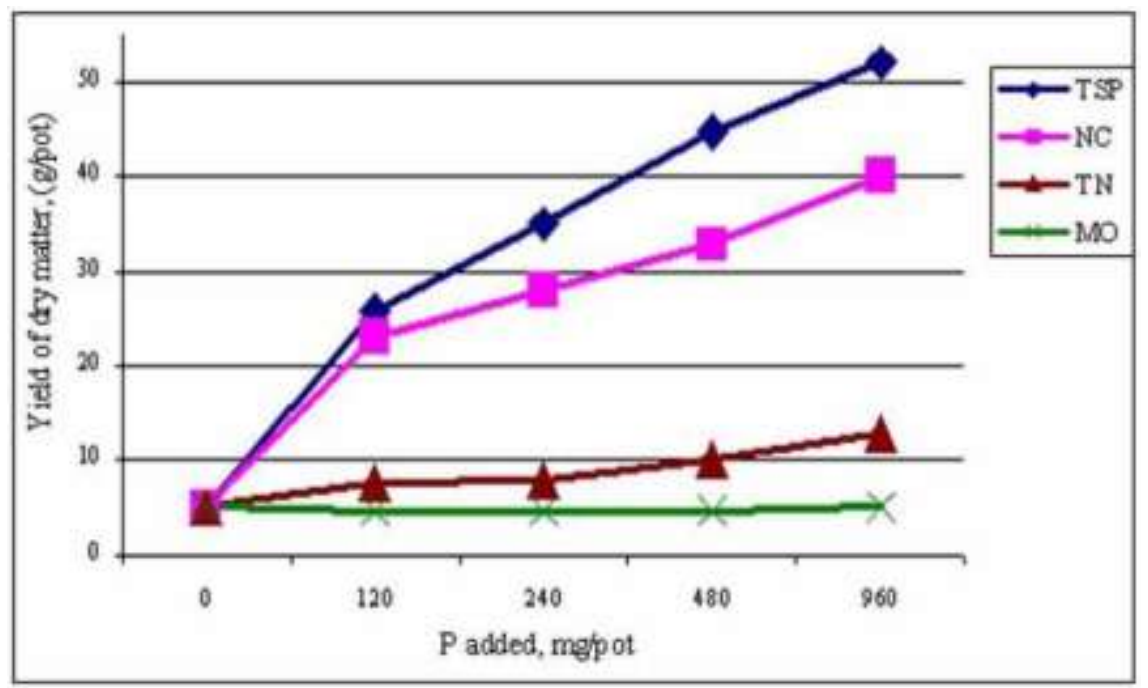

Fig. 5. Response of maize to different American sources of rock-phosphates.

They added that such differences are not related to $\mathrm{P}$ concentration in RP but most probably due to their geological nature and to the structure of other components in the rock phosphate.

Most of Egyptian rock phosphate sources, are very suitable for direct application as phosphate Fertilizers. In this work, the following sources are utilized:

1. Magnetic concentrate $\left(29 \% \mathrm{P}_{2} \mathrm{O}_{5}\right)$ from Abo- Tartour RP mine, New valley.

2. Sedimentary RP $\left(26 \% \mathrm{P}_{2} \mathrm{O}_{5}\right)$ from Isna region (Upper Egypt).

Fine particles of RP are mixed with elemental S, bentonite clay and acid producing microbial medium to form Agrite Phosphates. Phosphates in such mixture are not susceptible to fixation or leaching. It works as a safe P store that provides plants with their daily needs of nutrient Phosphorous all the year around. Due to inoculation with acid producers, Agrite Phosphate continuously releases phosphate into the soil solution, in an available from. Other nutrients- 
rich minerals are incorporated in this fertilizer mixture, the utilization of Agrite Phosphates as a phosphate fertilizer is considered a unique solution for most of the problems confronting phosphate fertilization. Agrite Phosphate passed several field tests and evaluations in different Egyptian soils; it proved to be a superior long acting $\mathrm{P}$ fertilizer compared to many others.

Field applications of Agrite Phosphate, in soils, have indicated top effect on the mobilization of $\mathrm{P}$ to the Rhizo- sphear of corn plants and consequently optimum P uptake (Fig. 6).

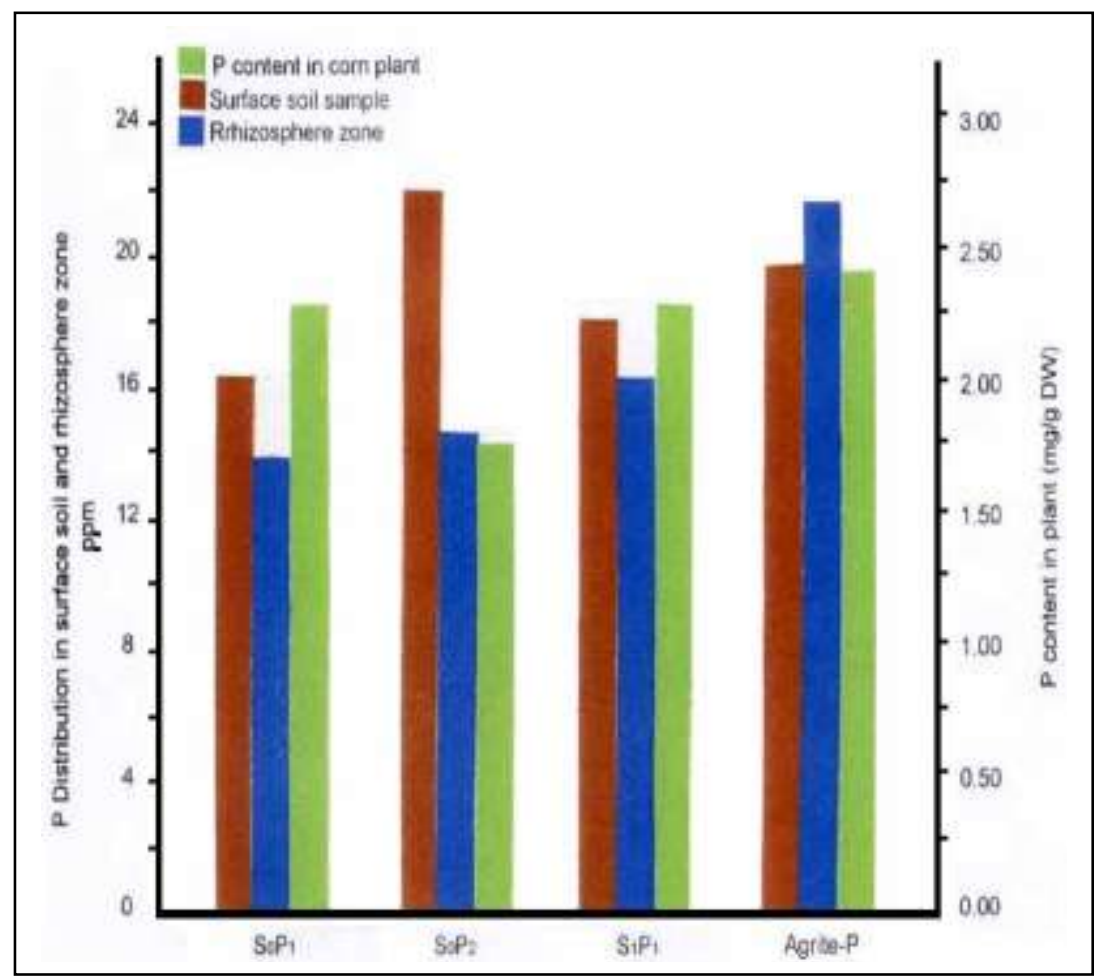

Fig. 6. Effect of $S$ and $P$ treatments on $P$ distribution in soils and $P$ content in plant.

Besides, Agrite Phosphate gave the maximum yield of maize and its uptake of $\mathrm{P}, \mathrm{Fe}$ and $\mathrm{Zn}$ compared to other amendments (Table 5).

TABLE 5. Effect of Agrite Phosphorus and farm manure on, total uptake of $\mathrm{P}, \mathrm{Fe}$ and $\mathrm{Zn}$, and grain yield of maize crop.

\begin{tabular}{|c|c|c|c|c|c|}
\hline Soil & Day weight & Grain yield & \multicolumn{3}{|c|}{ Shoot uptake (mg/Plant) } \\
\cline { 4 - 6 } Amendments & g/Plant & kg/fed & $\mathbf{P}$ & $\mathbf{F e}$ & $\mathbf{Z n}$ \\
\hline Control & 164 & 3340 & 354 & 33.1 & 7.1 \\
\hline S & 198 & 3840 & 445 & 46.5 & 12.9 \\
\hline Farm-manure & 216 & 4000 & 508 & 63.7 & 15.0 \\
\hline Agrite P & 230 & 4440 & 551 & 64.4 & 17.5 \\
\hline
\end{tabular}

Egypt. J. Soil Sci.. 53, No. 3 (2013) 


\section{Conclusions}

1. Application of elemental sulfur (inoculated with thio bacillus) to soils, lowers soil $\mathrm{pH}$, improves soil structure, and increases the availability of certain plant nutrients, notably phosphorus

2. When the sulfur treated soil was enriched with phosphate fertilizer; available phosphate was almost doubled in certain soils while no response to sulfur application appeared in other soils, even when enriched with phosphates.

3. Phosphate retained in clay soils was easily released, in a short time after application. While that retained in calcareous soils, in few hours after application, was difficult to recover.

4. The application of clays to soils of $\mathrm{CaCO}_{3}$ /clay ratio $\geq 1.25$ is expected to cause a great increase in crop yield and nutrients uptake upon sulfur and $\mathrm{P}$ application.

5. The quick retention of almost all the soluble phosphate fertilizers in soils, convert them to far less mobile forms. It follows that existing differences among soluble and rock phosphate fertilizers, count less in few weeks after being added to soils.

6. Only few sources of rock phosphates can perform well when applied directly to soils as fertilizers. The relative agronomic effectiveness of different sources of rock phosphates were not related to $\mathrm{P}$ concentration in rocks. However, acidified rock phosphate proved to be much more efficient than super-phosphate.

7. Agrite Phosphate fertilizer is a mixture of powder rock phosphate particles, elemental $\mathrm{S}$, bentonite clay and acid producing microbial medium.

8. The utilization of Agrite Phosphates as a phosphate fertilizer presents a unique solution for most of the problems confronting phosphate fertilization. It proved to be a superior long acting $\mathrm{P}$ fertilizer compared to many other $\mathrm{P}$ fertilizers.

\section{References}

Besharati, H. et al (2007) Biosuper as a phosphate fertilizer in a calcareous soil with low available phosphorus. African Journal of Biotechnology 6 (11): 1325-1329.

Burns, G.R. (1984) Oxidation of sulfur in soils The Sulphur Institute, Technical Bulletain, No. 13.

El-Neklawy, A.S. (1974) Phosphorus fixation in sandy, clayey and calcareous soils. M.Sc. Thesis, Cairo Univ., Egypt.

Hassan, N. and Olsen, R.A. (1966) Influence of applied sulfur on availability of soil nutrients for corn nutrition. Soil Sci. Amer. Proc. 30(2): 284-286.

Hilal, M. H. (1990) Sulfur in Desert Agro- Systems. Middle East Sulfur Symposium, Cairo, 12-16 Feb, 1990.

Hilal, M.H., Abed, F.M. and Bader, M.A. (1997) Corrective Techniques for Soil and Irrigation Water Salinity in Desert Agro-Systems. The International Symposium on 
Sustainable Management of Salt Affected Soils in the Arid Ecosystem, 21-26 Sep., Cairo, Egypt. p. 320.

Hilal, M. H., Shata, S. M., Abdel Dayem, A.A. and Helal, M.M. (2002) Application of Magnetic Technologies In Desert Agriculture: III. Effect of Magnetized water on yield and uptake of Certain Elements by citrus in Relation to nutrients mobilization in soil. Egypt. J. Soil Sci. 42 (1): 43-55.

Jones, RK. and Field, JBF. (1978) A comparison of biosuper and superphosphate on a sandy soil in the monsoonal tropics of north Queensland. Australian Journal of Experimental Agriculture and Animal Husbandry 16(78): 99 - 102.

Khasawneh, F. E. and Doll, E. C (1978) The use of phosphorus rock for direct application to soils. Adv. Agro. 30: 159-206.

Lee, A., Watikinson, J.H. and Lauren, D.R. (1988) Factors affecting oxidation rates of elemental sulfur in a soil under rye grass. Soil Biology and Biochemistry 20: 809-816.

Mahmoud, S.M. (1999) Effect of the application of sulfur fertilizer mixtures on the movement of some nutrients in the rhizosphere zone. M.Sc. Thesis, Ain Shams University, Egypt .

(Received 31/10/2012; accepted $30 / 3 / 2014)$ 


\section{دور الكبريت في الزراعة المصرية "مخلوط الفوسفات والكبرت \\ والبنتونيت لتعظيم إستخدام صخر الفوسفات للتسميد" للفيرة

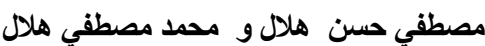

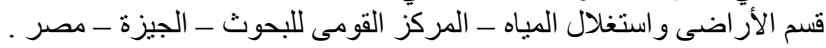

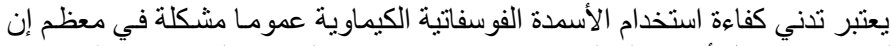

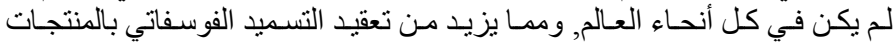

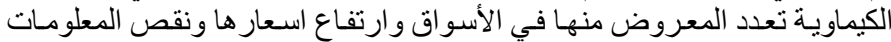

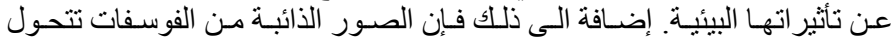
بسر عة بعد إضافتها الى التربة الى صور قليلة او عديمة الذوبان.

وكان مسحوق صخر الفوسفات يستخدم في الماضي للتسميد المبانثر للأراضي

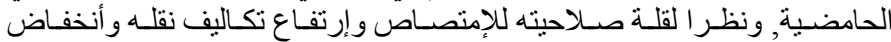

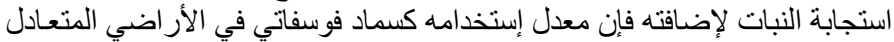

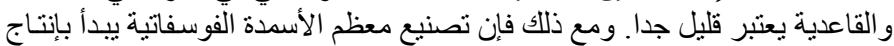

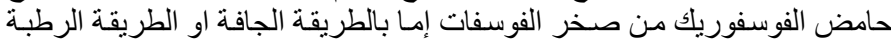

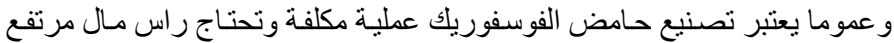

نسبيا.

ونوهت در اسة امريكية سابقه إلى وجود اختلاف كبير فى سلوك خامات صخر

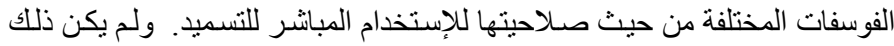

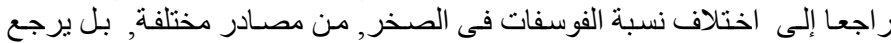

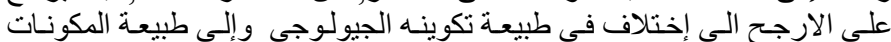

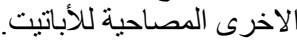

ولقد اكدت نتائج التجارب الحقلية لهذه الدر اسـة دور الكبريت في تعظيم كفاءة

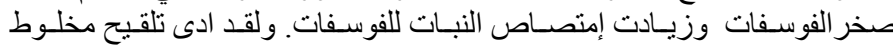

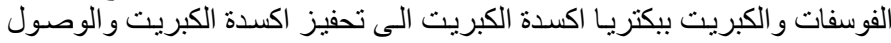

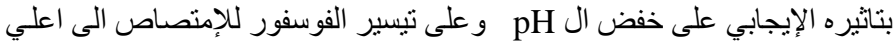

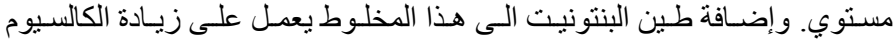

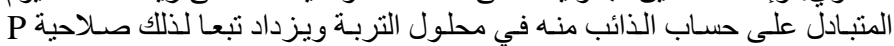

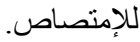

وتم إنتاج مخلوط خاص من كل المكونـات السـابقة " بواسطة شركة الجيزة

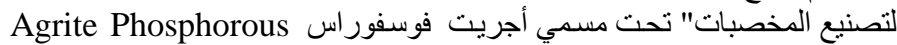
ولقد ثبت تفوقه على العديد من صبور الفوسفات الأخرى. 